\title{
Extracellular serine proteases by Acremonium sp. L1-4B isolated from Antarctica: Overproduction using cactus pear extract with response surface methodology
}

\author{
Talita Camila Evaristo da Silva Nascimento ${ }^{\mathrm{a}}$, Amanda Reges de Sena ${ }^{\mathrm{b}}$, \\ José Erick Galindo Gomes ${ }^{c}$, Wellington Leal dos Santos ${ }^{\mathrm{d}}$, \\ Gualberto Segundo Agamez Montalvo ${ }^{e}$, Elias Basile Tambourgi ${ }^{\mathrm{f}}$, \\ Erika Valente de Medeiros ${ }^{\mathrm{d}}$, Lara Durães Sette ${ }^{\mathrm{g}}$, Adalberto Pessoa Junior ${ }^{\mathrm{h}}$, \\ Keila Aparecida Moreira ${ }^{\mathrm{d}, *}$ \\ a Department of Morphology and Animal Physiology, Federal Rural University of Pernambuco, Pernambuco, Brazil \\ ${ }^{\mathrm{b}}$ Microbiology Laboratory, Federal Institute of Education, Science and Technology of Pernambuco, Pernambuco, Brazil \\ ${ }^{\mathrm{c}}$ Laboratory of Biochemistry and Applied Microbiology, São Paulo State University, São Paulo, Brazil \\ ${ }^{\mathrm{d}}$ Academic Unit of Garanhuns, Federal Rural University of Pernambuco, Pernambuco, Brazil \\ e Institute of Mathematics and Statistics, University of São Paulo, São Paulo, Brazil \\ ${ }^{\mathrm{f}}$ Department of Engineering of Chemical Systems, University of Campinas, São Paulo, Brazil \\ ${ }^{\mathrm{g}}$ Department of Biochemistry and Microbiology, São Paulo State University, São Paulo, Brazil \\ h Department of Biochemical and Pharmaceutical Technology, University of São Paulo, São Paulo, Brazil
}

\section{A R T I C L E I N F O}

\section{Article history:}

Received 25 August 2015

Accepted 13 October 2015

Available online 26 October 2015

\section{Keywords:}

Filamentous fungus

Psychrophilic microorganisms

Cactus

Optimization

Bioconversion

\begin{abstract}
A B S T R A C T
Acremonium sp. L1-4B isolated from lichen in Antarctica was used to produce extracellular proteases through submerged fermentation using cactus pear extract (Opuntia ficus-indica Mill.). A $2^{3}$ factorial design was applied to optimize the protease production using three independent variables, namely temperature, $\mathrm{pH}$ and concentration of yeast extract, was also used a Central Composite Design (CCD) under Response Surface Methodology (RSM). All variables and interactions analyzed in the factorial design were significant or marginally significant, a Central Composite Design was developed, and the Response Surface Methodology towards the highest point it was established. The experimental model was validated under $14{ }^{\circ} \mathrm{C}, \mathrm{pH} 7.54$, and $0.55 \%$ yeast extract, showing a protease activity of $447.65 \pm 2.6 \mathrm{U} / \mathrm{mL}$ by a prediction model of $445.48 \mathrm{U} / \mathrm{mL}$. The enzyme showed a molecular weight of $59 \mathrm{kDa}$; it was inhibited in the presence of PMSF (serine protease); it presented optimal conditions at $\mathrm{pH}$ 8.0 and $50{ }^{\circ} \mathrm{C}$; it remained stable at $\mathrm{pH}$ in the 3.0-9.0 range and between 10 and $40{ }^{\circ} \mathrm{C}$; it showed a tolerance to $3000 \mathrm{mM} \mathrm{NaCl}$ as well as to surfactants, hydrogen peroxide and urea at 5\%. This paper presents a proposal for an economically attractive production methodology using cactus pear as a primary source of carbon. In addition, the protease secreted by Acremonium sp. L1-4B presented a combination of biochemical characteristics that grants a promising variability of biotechnological applications.
\end{abstract}

(c) 2015 Elsevier Ltd. All rights reserved.

\section{Introduction}

Extremophile microorganisms are molecularly adapted to the

\footnotetext{
* Corresponding author.

E-mail addresses: talitacamila07@gmail.com (T.C.E.d.S. Nascimento), amandareges@gmail.com (A.R.d. Sena), erick.galindo.zoo@hotmail.com (J.E.G. Gomes), wellingtonleal16@gmail.com (W.L.d. Santos), gsagamez@gmail.com (G.S. Agamez Montalvo), eliastam@feq.unicamp.br (E.B. Tambourgi), evmbio@gmail.com (E.V.d. Medeiros) larasette@rc.unesp.br (L.D. Sette), pessoajr@usp.br (A. Pessoa Junior), moreirakeila@hotmail.com (K.A. Moreira).
}

development and spread in hostile environments. They are commonly subjected to various stress conditions such as high or low temperatures, extreme $\mathrm{pH}$, different salt concentrations, high levels of radiation and pressure, and water and nutrient restrictions (Gomes and Steiner, 2004).

Enzymes synthesized by psychrophilic microorganisms have developed a variety of structural features that grants them a high degree of flexibility, a low activation enthalpy and a high specific activity at low temperatures, so that these biocatalysts have attracted great attention for applications that seek to reduce energy consumption (Joshi and Satyanarayana, 2013; Siddiqui and Cavicchioli, 2006).

Secretion of enzymes by microorganisms is generally affected by physical-chemical and nutritional conditions. The evaluation 
process of the components of the environment and the optimization of parameters such as $\mathrm{pH}$ and temperature is a crucial step for enzyme production in commercial practice. In order to analyze the influence of these elements, the response surface methodology it has been commonly used (Fleuri and Sato, 2008; Joshi and Satyanarayana, 2013).

The use of agricultural and agro-industrial waste products in bioprocesses has shown a relevant productive viability in obtaining enzymes with an industrial and an economic interest. Castro and Sato (2013) suggest a combination of residues in the fermentation process for obtaining synergistic enzymes such as protease and $\alpha$-amylase. Maciel et al. (2011) cactus used as substrate in solid fermentation to produce pectinolytic enzymes with Aspergillus niger. In submerged fermentation, Gomes et al. (2014) used a medium consisting of cactus pear, bark of cassava and corn steep liquor, obtaining a significant production of cellulases, xylanases and phytases from Aspergillus tamarii.

The cactus pear (Opuntia ficus-indica Mill.) is a widely cultivated cactus in northeastern Brazil. It has a moderate nutritional value and is largely used as forage for ruminant herds and less significantly as human food (Bezerra et al., 2012; Oliveira et al., 2011). The genus Opuntia is known as a producer of mucilage, a complex carbohydrate with excellent water absorption capacity (Sáenz et al., 2004).

Aiming to establish parameters for the production of proteases through a filamentous fungus isolated in Antarctica, experimental models were employed in order to enable the use of cactus pear as a major substrate in the fermentation process, and thus detect the biochemical characteristics of the enzyme obtained in the study.

\section{Materials and methods}

\subsection{Microorganism and inoculum}

In this study, the filamentous fungus Acremonium sp. L1-4B isolated from a lichen sample on the Antarctic continent was used. It is preserved in the research collection associated with the Brazilian Collection of Microorganisms of Environment and Industry (CBMAI). The line was reactivated in agar Potato Dextrose Agar at $15^{\circ} \mathrm{C}$ for $360 \mathrm{~h}$. The inoculum was standardized in a $\mathrm{NaCl}$ solution $(0.3 \%)$ and Tween $80(0.1 \%)$ containing $10^{6}$ conidia per $\mathrm{mL}$.

\subsection{Production of proteases}

The production of proteases occurred with cactus pear being used as the main carbon source. The cladodes of the cactus pear were obtained in the municipality of Garanhuns-PE, Northeastern Brazil, subjected to a cleaning process with sodium hypochlorite at $2 \%$ for 20 seconds, then with two washings with distilled water. The processing of cladodes was made in a processor and the obtained cactus pear extract was diluted in the ratio $1: 5(\mathrm{v} / \mathrm{v})$ with $\mathrm{H}_{2} \mathrm{O}$ deionized and stored at $-20^{\circ} \mathrm{C}$. The carbon-nitrogen ratio of the validated medium (Section 2.5) was equal to $5.54 \mathrm{~g}$ (g carbon/g nitrogen). All production tests were conducted in Erlenmeyer flasks with a $125 \mathrm{~mL}$ capacity containing $25 \mathrm{~mL}$ of culture medium consisting of cactus pear extract associated with different yeast extract concentrations, $\mathrm{pH}$ and temperatures as described in the experimental design (Sections 2.3 and 2.4). The fermentation in a cooled incubator (model TE-422, TECNAL, Piracicaba, Brazil) lasted $96 \mathrm{~h}$ under orbital shaking at $120 \mathrm{rpm}$.

2.3. Evaluation of influence of different factors on enzyme production using $2^{3}$ factorial design

A $2^{3}$ factorial design was used with three central points, totaling 11 trials, in order to identify factors or independent variables that
Table 1

Actual and coded values for optimization of production of proteases by Acremonium sp. L1-4B, using Central Composit Design.

\begin{tabular}{|c|c|c|c|c|c|c|}
\hline \multirow[t]{2}{*}{ Independent variables } & \multirow[t]{2}{*}{ Unit } & \multicolumn{5}{|c|}{ Levels } \\
\hline & & $-\alpha^{*}$ & -1 & $\mathbf{0}$ & +1 & $+\alpha$ \\
\hline Temperature & ${ }^{\circ} \mathrm{C}$ & 13.0 & 14.0 & 15.0 & 16.0 & 17.0 \\
\hline $\mathrm{pH}$ & & 6.5 & 7.0 & 7.5 & 8.0 & 8.5 \\
\hline Yeast extract & $\%$ & 0.0 & 0.2 & 0.4 & 0.6 & 0.8 \\
\hline
\end{tabular}

$* 1.682$.

significantly influence enzyme production. In design, yeast extract concentration, temperature and $\mathrm{pH}$ of secretion of proteases was evaluated.

\subsection{Optimizing of production through Central Composite Design}

Central Composite Design was employed to determine the best conditions for enzyme production. The design contained three variables, six axial points and four central points, totaling 18 assays. All variables were studied in five levels $(-\alpha,-1,0,1, \alpha)$. In order to predict the production of the enzyme under the conditions of significant variables, the Response Surface Methodology was applied (Table 1).

The system behavior was explained by quadratic equation (Eq. (1)).

$Y=\beta_{0}+\beta_{1} A+\beta_{2} B+\beta_{3} C+\beta_{11} A^{2}+\beta_{22} B^{2}+\beta_{33} C^{2}+\beta_{12} A B+\beta_{13} A C+\beta_{23} B C+\varepsilon$

where $Y$ is the experimental response, $\beta_{0}$ is the intercept, $\beta_{1}, \beta_{2}$ and $\beta_{3}$ are the linear coefficients, $\beta_{11}, \beta_{22}$ and $\beta_{33}$ are the quadratic coefficients, $\beta_{12}, \beta_{13}$ and $\beta_{23}$ are coupling coefficients and $A, B, C$, $A^{2}, B^{2}, C^{2}, A B, A C$ and $B C$ are independent variables and $\varepsilon$ the experimental error.

\subsection{Validation of the statistical model}

To validate the composition of the medium, three additional experiments were conducted under conditions predicted for enzyme production. Protease activity in the enzyme extract was used as a dependent variable in the comparative study.

\subsection{Statistical analysis}

The results obtained in $2^{3}$ factorial and Central Composite Design were processed in the Statistica 8.0 software (StatSoft Inc., Tulsa, OK, USA), to indicate the effects statistically significant $(p<0.05)$ or marginally significant $(p<0.1)$, and model adjustment to experimental data. All experiments were performed at random.

\subsection{Protease activity}

The protease activity was determined using azocasein (Sigma Aldrich, St. Louis, MO, USA) as a substrate according to the method described by Charney and Tomarelli (1947), with modifications. The reaction mixture containing $0.5 \mathrm{~mL}$ of azocasein at $0.5 \%(\mathrm{w} / \mathrm{v})$ in a $50 \mathrm{mM}$ sodium acetate buffer, $\mathrm{pH} 5.0$ and $0.5 \mathrm{~mL}$ enzyme extract was incubated at $37^{\circ} \mathrm{C}$ for $40 \mathrm{~min}$. Then, $0.5 \mathrm{ml}$ of trichloroacetic acid at $10 \%$ was added and centrifuged at $4000 \mathrm{~g}$ for 10 min at $4{ }^{\circ} \mathrm{C}$ (model MIKRO $200 \mathrm{R}$, Andreas Hettich GmbH \& Co. $\mathrm{KG}$, Germany). An aliquot of $0.5 \mathrm{~mL}$ of the supernatant was added to $0.5 \mathrm{~mL}$ of potassium hydroxide at $500 \mathrm{mM}$. A protease unit was defined as the amount of enzyme capable of producing an increase of 0.001 in absorbance per minute of reaction at the wavelength of $430 \mathrm{~nm}$, in UV-Visible spectrophotometer, model Libra S22 
(Biochrom ${ }^{\circledR}$, Cambridge, England). The denatured enzyme was used as a negative control.

\subsection{Biochemical properties of the protease produced by Acremonium sp. $L 1-4 B$}

The crude enzyme extract resulting from statistical validation test was submitted to a biochemical characterization study.

\subsubsection{Temperature and optimal $\mathrm{pH}$}

To determine the optimal temperature of the protease, the enzyme extract was incubated in the range $10-80^{\circ} \mathrm{C}$. The optimal $\mathrm{pH}$ of the enzyme was determined using the buffers sodium citrate ( $\mathrm{pH} 3.0 ; 4.0)$, sodium acetate ( $\mathrm{pH} 5.0)$, sodium phosphate $(\mathrm{pH} 6.0$; $7.0)$ and $\mathrm{Tris}-\mathrm{HCl}(8.0 ; 9.0)$ at $50 \mathrm{mM}$. The results of optimal temperature and $\mathrm{pH}$ were expressed in relative activity (\%).

\subsubsection{Stability to temperature and $\mathrm{pH}$}

Thermal and $\mathrm{pH}$ stability were evaluated by incubating the enzyme extract for $180 \mathrm{~min}$ under the same conditions of temperature and $\mathrm{pH}$ described in the previous assay (Section 2.8.1). They were expressed as residual activity (\%).

\subsubsection{Effect of $\mathrm{NaCl}$ in the catalytic reaction}

To determine the effects of $\mathrm{NaCl}$ on protease activity, the azocasein substrate was prepared with different concentrations of $\mathrm{NaCl}(0-3000 \mathrm{mM})$ and the results were expressed in relative activity (\%).

\subsubsection{Effect of surfactants and other substances in the enzymatic activity}

The following components were evaluated: surfactant Triton X-100 (5\%), Tween 20 (5\%), Tween 80 (5\%) and Polyethylene glycol 2000 (5\%); chemical denaturant urea (5\%), bleaching agent $\mathrm{H}_{2} \mathrm{O}_{2}$ (5\%) and $\beta$-mercaptoethanol reducer ( 1 and $5 \mathrm{mM}$ ). The enzyme extract was previously incubated for $30 \mathrm{~min}$ at $26 \pm 2{ }^{\circ} \mathrm{C}$ together with the measured substance. The relative activity was determined using the enzyme extract without addition of agents as a control.

\subsubsection{Effect of protease inhibitors}

The effect of different inhibitors such as iodoacetic acid (1 and $10 \mathrm{mM}$ ); phenylmethylsulfonyl fluoride (PMSF; 1 and $10 \mathrm{mM}$ ); pepstatin $A(1 \mathrm{mM})$ and ethylenediaminetetraacetic (EDTA; 1 and $10 \mathrm{mM}$ ) were evaluated. The enzyme extract was incubated for 30 minutes with the inhibitor and then an aliquot was removed and subsequently subjected to detection of enzyme activity. The results were calculated relative to the control without inhibitor.

\subsection{Determination of the molecular weight and zymography}

The electrophoresis with polyacrylamide gel containing sodium dodecyl sulfate (SDS-PAGE) was performed according to the method described by Laemmli (1970), using a stacking gel at 4\% and a resolution of $13.75 \%$, GE Healthcare molecular weight standard (LMW Calibration Kit For SDS Electrophoresis, Amersham Place, England). The run proceeded at $4{ }^{\circ} \mathrm{C}, 284 \mathrm{~V}, 25 \mathrm{~mA}, 7 \mathrm{~W}$ for $81 \mathrm{~min}$. The gel was stained in a solution containing Comassie Brilliant Blue R250 0.25\% (w/v) for $120 \mathrm{~min}$ and destained in a solution containing $45 \%$ methanol, $45 \%$ water and $10 \%$ acetic acid for $24 \mathrm{~h}$. Subsequently, it was subjected to GE Healthcare silver staining (Silver Staining Protein kit, protein, Uppsala, Sweden). The molecular weight was estimated using the Lablmage 1D image analysis software (Loccus, Cotia, São Paulo, Brazil). The zymography was performed according to Egito et al. (2007), with modifications, using gelatin as substrate $(0.2 \mathrm{mg} / \mathrm{mL})$. The run was performed at $4{ }^{\circ} \mathrm{C}, 320 \mathrm{~V}, 50 \mathrm{~mA}, 16 \mathrm{~W}$ for $62 \mathrm{~min}$. The gel was incubated in a solution of Triton X-100 at $2.5 \%$ for 20 min at $4{ }^{\circ} \mathrm{C}$. Then, three washes were then made with water and incubated in a Tris- $\mathrm{HCl}$ buffer at $50 \mathrm{mM}, \mathrm{pH} 7.5$, containing $\mathrm{CaCl}_{2}, 15 \mathrm{Mm}$, for $120 \mathrm{~min}$ at $37{ }^{\circ} \mathrm{C}$. The gel was stained and destained with the same solutions used for the electrophoresis. However, the destaining occurred until a hydrolysis zone visible was visible.

\section{Results and discussion}

3.1. Evaluation of influence of different factors on enzyme production using $2^{3}$ factorial statistical design

Data from $2^{3}$ factorial design showed a variation of protease activity secreted by Acremonium sp. L1-4B from 0.07 to $191.32 \mathrm{U} / \mathrm{mL}$, indicating the importance and the need to use experimental designs to achieve higher yields of enzyme production. The difference between the lowest and highest (tests 6 and 3, respectively) showed an increase of approximately 2.733 times of the response variable, so it can be foreseen that the compositional parameters of the assay 3 may possibly provide better stimulus conditions for the expression and consequently the production of protease by Acremonium sp. L1-4B (Table 2).

The results as assessed by analysis of variance (ANOVA) (Table 3 ), revealed that the regression was statistically significant and the lack of fit not was statistically significant. The model adjustment was measured by the coefficient of determination $\left(R^{2}\right)$ which had a value of 0.9333 and $R_{A d j}^{2}=0.8334$. Indicating that $93.33 \%$ of the total variation in residual activity was explained by the adjusted model.

On the other hand, it was found that all independent variables and their interactions are statistically significant $(p<0.05)$ or marginally significant $(p<0.10)$ (Table 4$)$. The interaction refers to the combined or synergistic action of two or more factors, or the interaction of two or more factors is related to the fact that the effect of the level of one of them depends on the level of the other.

It was found that the factors temperature and yeast extract (both statistically significant) have negative effects, indicating that, when increasing the temperature from 15 to $25^{\circ} \mathrm{C}$ and the concentration of yeast extract from $0.5 \%$ to $1.5 \%$, there was a decrease in the production of protease. As the $\mathrm{pH}$ was marginally significant factor and their interactions were statistically significant, it was determined to continue in the direction of the interaction effect of greater magnitude (Table 4).

In a work by Badoei-Dalfard and Karami (2013), the authors found that temperature, $\mathrm{pH}, \mathrm{MgSO}_{4}$ and $\mathrm{NaCl}$ were the variables that most influenced the production of protease by Bacillus sp., using the Plackett-Burman design, since it was statistically significant $(p<0.05)$, that is, they affected the production of protease,

Table 2

Matrix of the $2^{3}$ fractional design with three center points associated with response variable total activity of proteases produced by Acremonium sp. L1-4B.

\begin{tabular}{llllc}
\hline Run & Temperature $\left({ }^{\circ} \mathbf{C}\right)$ & pH & Yeast extract $(\%)$ & Proteases activity $(\mathbf{U} / \mathbf{m L})$ \\
\hline 1 & 15.0 & 4.0 & 0.5 & $189.75 \pm 0.00$ \\
2 & 25.0 & 4.0 & 0.5 & $15.22 \pm 0.01$ \\
3 & 15.0 & 8.0 & 0.5 & $191.32 \pm 0.00$ \\
4 & 25.0 & 8.0 & 0.5 & $35.42 \pm 0.00$ \\
5 & 15.0 & 4.0 & 1.5 & $135.30 \pm 0.02$ \\
6 & 25.0 & 4.0 & 1.5 & $0.07 \pm 0.00$ \\
7 & 15.0 & 8.0 & 1.5 & $10.57 \pm 0.00$ \\
8 & 25.0 & 8.0 & 1.5 & $5.77 \pm 0.01$ \\
9 & 20.0 & 6.0 & 1.0 & $53.47 \pm 0.00$ \\
10 & 20.0 & 6.0 & 1.0 & $33.75 \pm 0.00$ \\
11 & 20.0 & 6.0 & 1.0 & $48.15 \pm 0.03$ \\
\hline
\end{tabular}


Table 3

Analysis of variance (ANOVA) for the production of protease by Acremonium sp. L1$4 \mathrm{~B}$ according to the $2^{3}$ factional design with three center points.

\begin{tabular}{llrlll}
\hline Source & Sum of squares & $\begin{array}{l}\text { Degrees } \\
\text { of } \\
\text { freedom }\end{array}$ & Mean square & F-Value & p-Value \\
& & 6 & 8072.66 & 9.34 & $0.0243^{*}$ \\
\hline Regression & 48435.98 & 4 & 864.32 & & 0.060 \\
Residual & 3457.29 & 2 & 1624.55 & 15.61 & \\
Lack of Fit & 3249.11 & 2 & 104.09 & & \\
Pure error & 208.18 & 10 & & & \\
Total & 51893.26 & 10 & &
\end{tabular}

* Statistically significant. Confidence level 95\%.

Table 4

Estimate of the effects of variables in production of protease by Acremonium sp. L1$4 \mathrm{~B}$ according to the $2^{3}$ factional design with three center points.

\begin{tabular}{llll}
\hline Variables & Effects & $\boldsymbol{t}$ & $\boldsymbol{p}$-Value \\
\hline (1) Temperature & -117.615 & -16.3032 & $0.003 \mathrm{~s}$ \\
(2) pH & -24.315 & -3.3704 & $0.077 \mathrm{~ms}$ \\
(3) Yeast extract & -70.000 & -9.7030 & $0.010 \mathrm{~s}$ \\
1 by 2 & 37.265 & 5.1655 & $0.035 \mathrm{~s}$ \\
1 by 3 & 47.600 & 6.5981 & $0.022 \mathrm{~s}$ \\
2 by 3 & -35.200 & -4.8792 & $0.039 \mathrm{~s}$ \\
\hline
\end{tabular}

ms: Marginally significant. s: Statistically significant. Confidence level 95\%.

showing positive effects. In the production of alkaline protease by Marinobacter sp. GA CAS9, the authors reported that the enzyme production was strongly influenced by $\mathrm{NaCl}$ concentration, meat extract, $\mathrm{CuSO}_{4}$, incubation temperature and initial $\mathrm{pH}$ values, obtaining values between 298.15 and $487.24 \mathrm{U} / \mathrm{mL}$ using the same statistical method, since the remaining parameters (lactose, $\mathrm{CuSO}_{4}$ and incubation time) were identical for these two activity extremes. However, the $\mathrm{pH}$ had a positive effect, and temperature and concentration of $\mathrm{NaCl}$ had negative effects (Kumar et al., 2014). It was shown that protease secretion in the studies described above was strongly influenced by physical-chemical parameters in the cultivation employing different microorganisms, thus highlighting the importance of using statistical tools for the modeling of the experimental design.

\subsection{Optimization of protease production using Central Composite Design}

A new experimental matrix was made to increase the production of protease by Acremonium sp. L1-4B, all variables were evaluated in five levels: temperature $\left(13,14,15,16\right.$ and $\left.17^{\circ} \mathrm{C}\right), \mathrm{pH}$ $(6.5,7.0,7.5,8.0$ and 8.5$)$ and concentration of yeast extract $(0.0$, $0.2,0.4,0.6$ and $0.8 \% \mathrm{w} / \mathrm{w}$ ). The levels of these factors have been modeled and the results of the predicted are presented in Table 5 .

The effects of variables were modeled and are presented in Table 6. Temperature, $\mathrm{pH}$ and yeast extract in their quadratic terms, had a negative effect, indicating a region of maximum protease production values at the center point or near it. An increase in $\mathrm{pH}$ (from 6.5 to 8.0 ) and in yeast extract concentration $(0-0.8)$ determined a higher protease production averaged 3.08 and $148.80 \mathrm{U} / \mathrm{mL}$, respectively. In linear term, the effect $\mathrm{pH}$ was not significant, the effect temperature was marginally significant $(p<0.10)$, and the only effect statistically significant $(p<0.05)$ was yeast extract. This is the variable with the greatest influence on enzyme production in the experimental field studied. In this way, Kammoun et al. (2008) reported that the use of organic nitrogen sources may have a significant effect on the production of enzymes, since it can have a natural and mineral percentage of carbon in its composition.
Table 5

Experimental matrix, results obtained in the CCD in the production of proteases by Acremonium sp. L1-4B and activity provided for in the model.

\begin{tabular}{lllllll}
\hline Run & Temperature $\left({ }^{\circ} \mathbf{C}\right)$ & $\mathbf{p H}$ & Yeast extract $(\%)$ & \multicolumn{2}{c}{ Proteases activity $(\mathbf{U} / \mathbf{m L})$} \\
\cline { 3 - 6 } & & & & Experimental & Predicted \\
\hline \multirow{2}{*}{} & & & & $401.70 \pm 4.24$ & 386.84 \\
2 & 16.0 & 8.0 & 0.6 & $373.20 \pm 0.85$ & 363.02 \\
3 & 14.0 & 8.0 & 0.2 & $440.85 \pm 1.06$ & 433.06 \\
4 & 16.0 & 7.0 & 0.6 & $369.75 \pm 1.06$ & 349.47 \\
5 & 15.0 & 7.0 & 0.2 & $451.50 \pm 4.67$ & 440.21 \\
6 & 15.0 & 7.5 & 0.4 & $431.25 \pm 8.70$ & 440.21 \\
7 & 15.0 & 7.5 & 0.4 & $423.00 \pm 2.97$ & 440.21 \\
8 & 15.0 & 7.5 & 0.4 & $394.05 \pm 7.85$ & 399.94 \\
9 & 15.0 & 6.5 & 0.4 & $304.05 \pm 3.18$ & 330.00 \\
10 & 16.0 & 7.5 & 0.0 & $374.85 \pm 1.06$ & 381.55 \\
11 & 13.0 & 7.0 & 0.6 & $380.25 \pm 6.15$ & 391.36 \\
12 & 15.0 & 7.5 & 0.4 & $422.85 \pm 1.91$ & 422.29 \\
13 & 15.0 & 7.5 & 0.8 & $459.45 \pm 5.73$ & 440.21 \\
14 & 14.0 & 7.5 & 0.4 & $381.45 \pm 8.70$ & 356.78 \\
15 & 14.0 & 8.0 & 0.2 & $350.25 \pm 5.30$ & 347.13 \\
16 & 17.0 & 7.0 & 0.2 & $339.00 \pm 3.39$ & 412.50 \\
17 & 15.0 & 7.5 & 0.4 & $393.00 \pm 6.36$ & 412.50 \\
18 & 14.0 & 8.5 & 0.4 & $432.15 \pm 1.91$ & 434.46 \\
\hline
\end{tabular}

Table 6

Estimate of the effects of variables in production of protease by Acremonium sp. L1$4 \mathrm{~B}$ according to $\mathrm{CCD}$ design.

\begin{tabular}{lccl}
\hline Variables & Effects & $\boldsymbol{T}$ & $\boldsymbol{p}$-Value \\
\hline Temperature $\left({ }^{\circ} \mathrm{C}\right)(\mathrm{L})$ & -22.64 & -2.46 & $0.091 \mathrm{~ms}$ \\
Temperature $\left({ }^{\circ} \mathrm{C}\right)(\mathrm{Q})$ & -48.00 & -5.014 & $0.015 \mathrm{~s}$ \\
pH $(\mathrm{L})$ & 7.47 & 0.81 & 0.476 \\
pH $(\mathrm{Q})$ & -24.03 & -2.51 & $0.087 \mathrm{~ms}$ \\
Yeast extract $(\%)(\mathrm{L})$ & 54.87 & 5.96 & $0.009 \mathrm{~s}$ \\
Yeast extract $(\%)(\mathrm{Q})$ & -45.30 & -4.73 & $0.018 \mathrm{~s}$ \\
Temperature $\left({ }^{\circ} \mathrm{C}\right) \times \mathrm{pH}$ & 1.95 & 0.16 & 0.881 \\
Temperature $\left({ }^{\circ} \mathrm{C}\right) \times$ Yeast extract $(\%)$ & -26.93 & -2.24 & 0.111 \\
pH $\times$ Yeast extract $(\%)$ & -4.13 & -0.34 & 0.754 \\
\hline
\end{tabular}

ms: Marginally significant. s: Statistically significant. Confidence level 95\%.

A multiple regression analysis based on the least squares method was performed using STATISTICA software Version 8.0. According to Eq. (2), the enzymatic activity followed a second order polynomial model with 10 coefficients.

Enzymatic activity

$$
\begin{aligned}
(\mathrm{U} / \mathrm{mL})= & -7941.71( \pm 2170.094)+721.02 \cdot T( \pm 170.102) \\
& -24.00 \cdot \mathrm{T}^{2}( \pm 4.786)+707.42 \cdot \mathrm{pH}( \pm 340.205) \\
& -48.06 \cdot \mathrm{pH}^{2}( \pm 19.146)+1754.53 \cdot \mathrm{YE}( \pm 645.914) \\
& -566.22 \cdot \mathrm{YE}^{2}( \pm 119.659)+1.95 \cdot \mathrm{T} \cdot \mathrm{pH}( \pm 12.037) \\
& -67.31 \cdot \mathrm{T} \cdot \mathrm{YE}( \pm 30.093)-20.62 \mathrm{pH} \cdot \mathrm{YE}( \pm 60.186)
\end{aligned}
$$

where $T$ is the temperature $\left({ }^{\circ} \mathrm{C}\right), Y E$ is yeast extract concentration (\%) and $\mathrm{pH}$ is hydrogenic potential.

The Analysis of Variance (ANOVA) for the response surface model represented in the Eq. (2), is presented in Table 7.

The Fisher-based test ( $F$ test) indicated that the adjusted equation 2 was statistically significant (Fcal $>$ Ftab) and the lack of fit showed a good concordance (Fcal $<$ Ftab) between the predicted response model and the experimental values. The quality of the model adjustment was measured by the coefficient of determination $\left(R^{2}\right) 0.8709$ and $R_{A d j}^{2}=0.7255$. This indicated that the adjusted model explained $87.09 \%$ of the total variation in the residual activity.

Optimized values are calculated by its partial differentiation with respect to temperature, $\mathrm{pH}$ and yeast extract. Response 
Table 7

Analysis of variance (ANOVA) for the data presented in Table 5.

\begin{tabular}{lrllllll}
\hline $\begin{array}{l}\text { Source of } \\
\text { variation }\end{array}$ & $\begin{array}{l}\text { Sum of } \\
\text { squares }\end{array}$ & $\begin{array}{l}\text { Degrees of } \\
\text { freedom }\end{array}$ & $\begin{array}{l}\text { Mean } \\
\text { square }\end{array}$ & Fcal & Ftab & $\boldsymbol{p}$-Value \\
\hline Regression & 29313.71 & 9 & 3257.08 & 6.94 & 3.39 & $0.005^{*}$ \\
Residual & 3754.88 & 8 & 469.36 & & & \\
Lack of fit & 2885.52 & 5 & 577.10 & 1.99 & 9.01 & 0.302 \\
Pure error & 869.35 & 3 & 289.78 & & & \\
Total & 29073.51 & 17 & & & & \\
\hline
\end{tabular}

* Statistically significant. Fcal: F calculated; Ftab: F tabled. Confidence level 95\%.

surface graphics Fig. 1(A, B, and C) were drawn to determine optimal levels of independent variables according to Eq. (2). Each response surface shows the effect of two factors, while the third was fixed at its central point.

The relative effect of $\mathrm{pH}$ and temperature on the production of protease is shown in Fig. 1(A). The change in temperature from $13^{\circ} \mathrm{C}$ to $14^{\circ} \mathrm{C}$ resulted in an increase of enzyme production averaged $20.93 \mathrm{U} / \mathrm{mL}$. There was a loss in enzyme activity (Fig. 1(B)) with the decrease in the concentration of yeast extract at higher temperature levels, fixating at $16{ }^{\circ} \mathrm{C}$. When decreasing the concentration of the yeast extract from $0.6 \%$ to $0.2 \%$, a loss in enzyme production averaged $34.32 \mathrm{U} / \mathrm{mL}$ was found. However, with a lower temperature $\left(14{ }^{\circ} \mathrm{C}\right)$ and an increase from $0.2 \%$ to $0.6 \%$ of yeast extract concentrations, the protease activity increased from 365.85 to $436.50 \mathrm{U} / \mathrm{mL}$. This indicates the presence of a negative interaction effect between these two variables in the production of protease (Tables 5 and 6 ).

In Fig. 1(C), it is possible to observe that, with a lower yeast extract concentration (0.0-0.2\%), enzyme production is reduced, regardless of the tested $\mathrm{pH}$. However, protease is secreted to the maximum between $0.4 \%$ and $0.7 \%$ of yeast extract, and at $\mathrm{pH} 7.2-$ 8.0. The use of the response surface methodology in this study allowed guiding safely and efficiently the parameters that directly influence the production of proteases, which only reinforces that reported by Mnif et al. (2012), according to which one of the devices used to provide more bioprocessing economy is the use of response surface methodology for optimization of medium components.

\subsection{Validation}

The results demonstrated a high degree of similarity between simulated and experimental data. The model was validated using the independent variables temperature $\left(14^{\circ} \mathrm{C}\right), \mathrm{pH}(7.54)$ and yeast
A

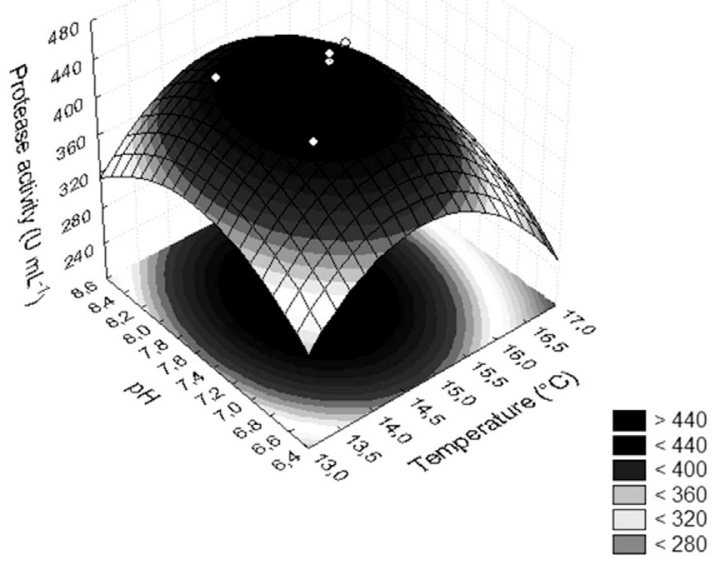

B

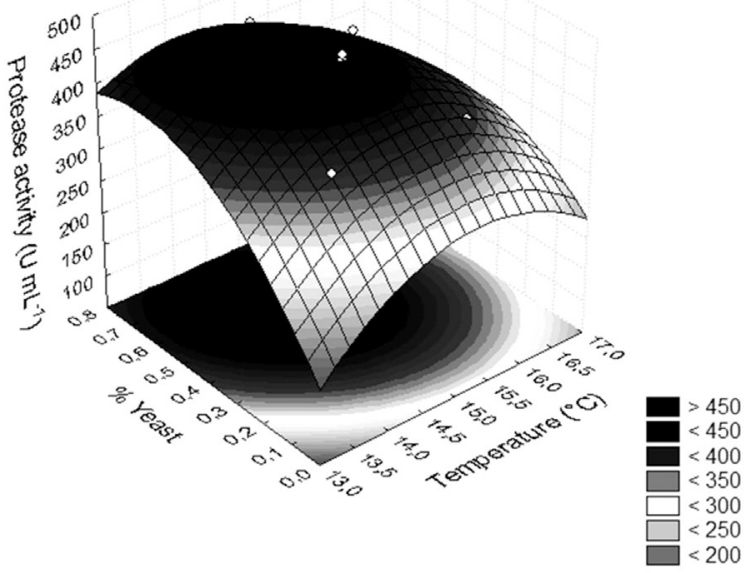

C

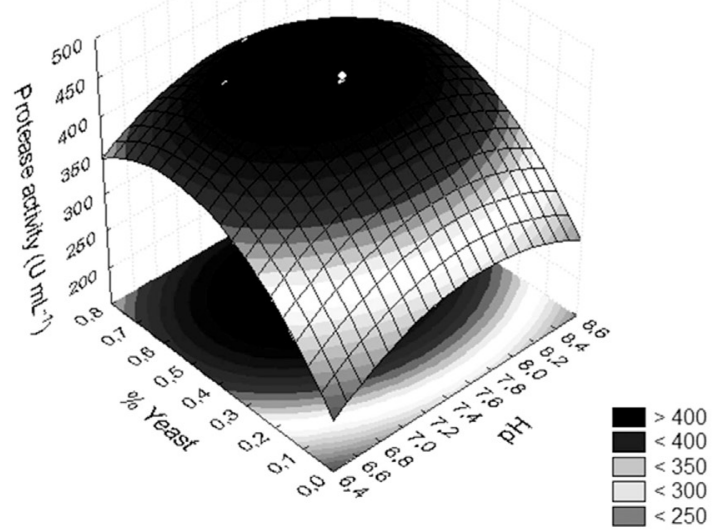

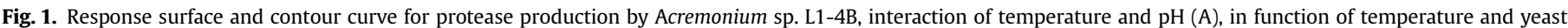
extract (B), and yeast extract and $\mathrm{pH}(\mathrm{C})$. 
extract $(0.55 \%)$. The proximity of the predicted response of protease activity $(445.48 \mathrm{U} / \mathrm{mL})$ and the experimental response $(447.65 \pm 2.6 \mathrm{U} / \mathrm{mL})$ defined the validation of the model. In this study, two statistical methods were used. It was thus possible to increase enzyme activity by 2.35 times (134.94\%) in optimal conditions when compared to the best conditions obtained in the factorial design. Shabbiri et al. (2012), using Central Composite Design, there was a 2.0 times increase in the production of protease by Brevibacterium linens DSM 20158. Meena et al. (2013), using Taguchi methodology with optimized conditions, the alkaline protease production by Pseudomonas aeruginosa increased by 1.29 time (28.8\%) In contrast, during the production of protease by Exiguobacterium sp. CFR26M after optimal conditions obtained in the CCD, the authors obtained a 6.30 times increase (Kumar and Suresh, 2014).

\subsection{Biochemical properties of the protease produced by Acremonium sp. $L 1-4 B$}

\subsubsection{Temperature and optimal $\mathrm{pH}$}

The enzyme exhibited a higher catalytic activity at $50^{\circ} \mathrm{C}$. However, it showed a relative activity above $20 \%$ at $10{ }^{\circ} \mathrm{C}$ and about $17 \%$ at $80{ }^{\circ} \mathrm{C}$ (Fig. 2(A)). The optimal protease was at $\mathrm{pH} 8.0$, showing a higher relative activity at $87 \%$ in the $\mathrm{pH}$ range $6.0-9.0$ (Fig. 2(B)). However, the biocatalysis was influenced negatively with $\mathrm{pH} 3.0$ and 4.0 , showing, respectively, $1 \%$ and $8.5 \%$ of relative activity under these conditions. The enzyme showed activation characteristics suggesting the high flexibility of the biomolecule, predisposed to catalyze at low and high temperatures, and a
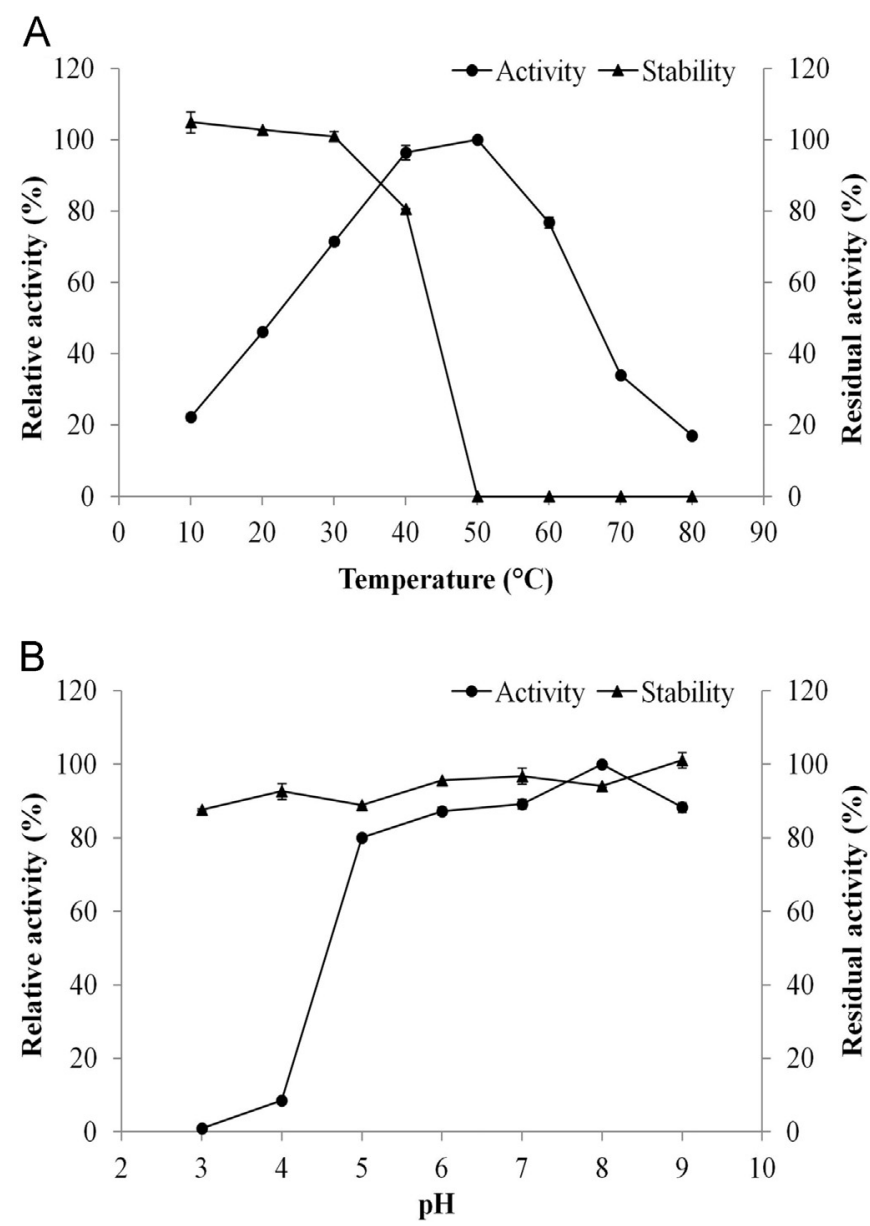

Fig. 2. Effects of temperature (A) and, $\mathrm{pH}(\mathrm{B})$ on activity and stability (180 minutes) of proteases produced by Acremonium sp. L1-4B. greater efficiency in the neutral and alkaline $\mathrm{pH}$ range. Similar results were found by Irwin et al. (2001), evaluating a protease secreted by marine psychrophilic strain PA-43, which showed a better activity between 55 and $60^{\circ} \mathrm{C}$ and $\mathrm{pH}$ 8.3. However, the protease of isolated bacteria Pseudoalteromonas sp. NJ276 in Antarctica showed its optimal value with a temperature of $30^{\circ} \mathrm{C}$ and $\mathrm{pH}$ 8.0. Although microorganisms come from cold environments, distinct characteristics may possibly be related to the genetic variability of the strains and their physiological adaptation (Wang et al., 2008). However, when evaluating the protease of a mesophile fungal, Abidia et al. (2011) found that the enzyme secreted by Botrytis cinerea showed similar characteristics to those found in this study at an optimal temperature of $50^{\circ} \mathrm{C}$ and $\mathrm{pH} 8.0$. Also studying mesophiles, Savitha et al. (2011), observed that proteases produced by Graphium putredinis demonstrated their optimal value at $50{ }^{\circ} \mathrm{C}$ at $\mathrm{pH}$ 7.0. On the other hand, the protein secreted by Trichoderma harzianum showed a higher catalytic activity at $60^{\circ} \mathrm{C}$ and pH 8.0. According to Shankar et al. (2011), pH affects the ionization of amino acids, which form the primary and secondary structures of the enzyme, and the temperature directly influences the speed of the enzymatic reaction. This statement is in agreement with the results found in this study, in which the temperature inferred directly in enzyme activation, and the strong acidification caused inactivation of the protein; possibly, the structure of its surface was altered, causing a lack of interaction between the catalytic site of the enzyme and its substrate.

\subsubsection{Stability to temperature and $p H$}

The protease secreted by the psychrophile Acremonium sp. L1$4 \mathrm{~B}$ showed to be thermally stable for $180 \mathrm{~min}$ at $10-40{ }^{\circ} \mathrm{C}$ temperature range, showing thermolability at temperatures above $50{ }^{\circ} \mathrm{C}$ (Fig. 2(A)). However, when contrasted with different $\mathrm{pH}$ ranges, the enzyme showed stability and a residual activity above $87 \%$ at all tested $\mathrm{pH}$ ranges at 180 min of testing (Fig. 2(B)). Wang et al. (2008) found that the protease of psychrophile Pseudoalteromonas sp. NJ276 remained stable at $30{ }^{\circ} \mathrm{C}$ for $50 \mathrm{~min}$; when incubated at $50{ }^{\circ} \mathrm{C}$, the enzyme lost $55 \%$ of its activity after $20 \mathrm{~min}$ and it was completely inactivated in $30 \mathrm{~min}$. However, it demonstrated stability in the $\mathrm{pH}$ range $7.0-9.0$ for $60 \mathrm{~min}$. Vázquez et al. (2008) observed that the enzyme from the Antarctic bacterium Pseudoalteromonas sp. P96-47 showed thermostability for 60 min when below $30^{\circ} \mathrm{C}$. However, it showed inactivation at $60{ }^{\circ} \mathrm{C}$ in the same time interval. It also showed a greater stability in neutral to alkaline $\mathrm{pH}$ ranges, maintaining more than $80 \%$ of the activity at pH 6-10 after 180 min of incubation at $4{ }^{\circ} \mathrm{C}$. On the other hand, proteases from the mesophile Bacillus subtilis AP-MSU6, investigated by Maruthiah et al. (2013), remained stable at temperatures of 40 and $150{ }^{\circ} \mathrm{C}$ for 50 and $75 \mathrm{~min}$, respectively. The enzymes showed stability at pH 9.0 for 180 minutes and at pH 10.0 for $90 \mathrm{~min}$. The results found in the studies described above only confirm that there is a strong interrelation between the original habitat of the microorganism and the characteristics of its biomolecules. According to Siddiqui and Cavicchioli (2006), proteins from psychrophiles exhibit more flexibility and thermolability than those secreted by its counterparts. The high flexibility of the molecule is accompanied by low stiffness, giving to the protein a lower enthalpy of activation but a greater thermal lability. However, the thermolability of the protease secreted by Acremonium sp. L1-4B, evaluated in this study, can also be considered as qualitative for the development of certain industrial processes. This is because, according to Vázquez et al. (2008), the thermal lability arising from microbial protease may also be a characteristic sought after in some biotechnological procedures, such as in the food industry, since they can be selectively inactivated in food cooking. In addition, the activity of these biomolecules can be exploited, for example, in the production of food hydrolysates, for it generates 


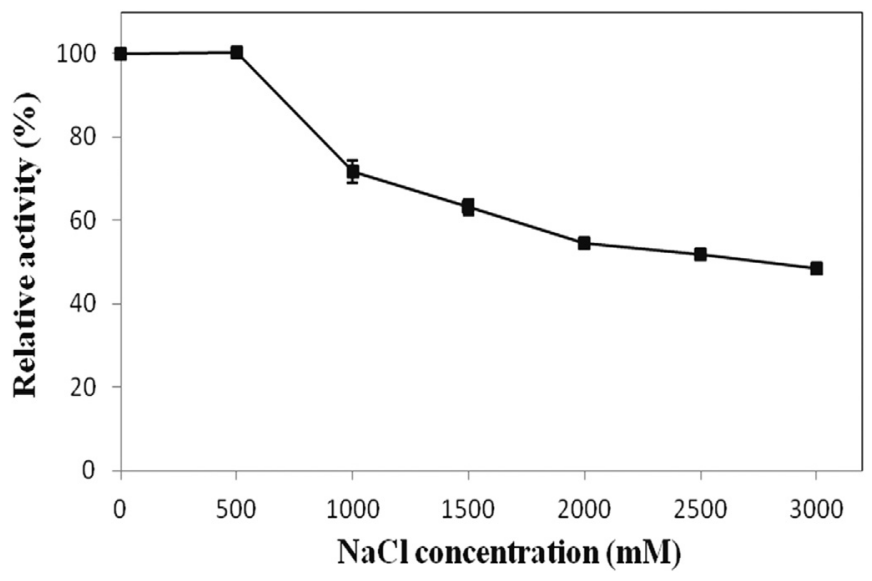

Fig. 3. Effect of $\mathrm{NaCl}$ concentration on catalytic activity of proteases produced by Acremonium sp. L1-4B.

less bitterness in food than when animal proteins are used.

\subsubsection{Effect of $\mathrm{NaCl}$ in the catalytic reaction}

The enzyme showed tolerance against $\mathrm{NaCl}$ concentrations ranging from 500 to $3000 \mathrm{mM}$. The relative activity of the enzyme in $500 \mathrm{mM}$ of $\mathrm{NaCl}$ remained at $100 \%$; with $1000 \mathrm{mM} \mathrm{NaCl}$, it decreased to $72 \%$. In summary, the progressive increase of salt concentration provided the decrease in enzyme activity. However, the relative activity was $48 \%$ when the catalyst occurred in the presence of $3000 \mathrm{mM} \mathrm{NaCl}$ (Fig. 3). Similar results were found in a study on proteases from the mesophile Bacillus subtilis AP-MSU 6, where Maruthiah et al. (2013) observed that there was a catalytic activity at concentrations from $500 \mathrm{mM}$ to $2500 \mathrm{mM}$ of $\mathrm{NaCl}$, showing $74.47 \%$ of relative activity at a concentration of $1000 \mathrm{mM}$ $\mathrm{NaCl}$ and approximately 40\% in $2500 \mathrm{mM}$. Annamalai et al. (2014), suggest that enzymes with a high tolerance to salt are indispensable tools in biotechnological processes dependent of high salinity or osmotic pressure.

\subsubsection{Effect of surfactants and other substances in the enzymatic activity}

The effects of surfactants, bleaching agents, denaturants and enzyme reducing are shown in Table 8. With the addition of Tween 20 and Tween 80 in the reaction mixture, there was a slight increase of $1 \%$ and $12 \%$, respectively, in the enzymatic activity in comparison with the control. However, the addition of Triton X-100 and PEG led to a catalytic decrease of $7 \%$ and $4 \%$, respectively. $\mathrm{H}_{2} \mathrm{O}_{2}$ enhanced the enzyme activity by $34 \%$. In the same way, there was an increase of $4 \%$ under the influence of urea. The reducing agent $\beta$-mercaptoethanol tested at concentrations of 1 and $5 \mathrm{mM}$ showed a decrease in catalysis of $4 \%$ and $7 \%$. Similar results obtained by Wang et al. (2008) were observed with active protease in cold temperatures, in which Tween 80 increased catalysis by $11 \%$. However, the addition of Triton X-100 and $\mathrm{H}_{2} \mathrm{O}_{2}$ showed, respectively, a decrease of $31.5 \%$ and $11.4 \%$. The protease of the thermophile evaluated by Zanphorlin et al. (2011) was negatively influenced in the presence of Triton X-100 and Tween 80, showing a decrease of $11.4 \%$ and $80 \%$, respectively. However, the relative activity was potentiated in the addition of Tween 20 at $17.2 \%$.

\subsubsection{Effect of protease inhibitors}

The enzyme extract was evaluated in comparison with protease inhibitors EDTA, iodoacetic acid, PMSF and pepstatin A. The enzyme secreted by Acremonium sp. L1-4B suffered inhibition in the presence of PMSF, showing at the end an activity of 6 and 3\% at
Table 8

Effects of surfactants, bleaching agent, chemical denaturant and inhibitors on proteases activity.

\begin{tabular}{lll}
\hline Chemical & Concentration & Relative activity $(\%)^{*}$ \\
\hline None & & 100 \\
Surfactants & & \\
Tween 20 & $5 \%(\mathrm{v} / \mathrm{v})$ & $101 \pm 2.4$ \\
Tween 80 & $5 \%(\mathrm{v} / \mathrm{v})$ & $112 \pm 1.0$ \\
Triton X-100 & $5 \%(\mathrm{v} / \mathrm{v})$ & $93 \pm 5.7$ \\
PEG 2000 & $5 \%(\mathrm{v} / \mathrm{v})$ & $96 \pm 4.6$ \\
Bleaching agent & $5 \%(\mathrm{v} / \mathrm{v})$ & \\
$\mathrm{H}_{2} \mathrm{O}_{2}$ & & $134 \pm 3.3$ \\
Desnaturant agent & $5 \%(\mathrm{w} / \mathrm{v})$ & $104 \pm 2.1$ \\
Urea & & \\
Reducing agent & $1 \mathrm{mM}$ & $96 \pm 2.7$ \\
$\beta$-mercaptoethanol & $5 \mathrm{mM}$ & $93 \pm 1.3$ \\
$\beta$-mercaptoethanol & & \\
Inhibitor & $1 \mathrm{mM}$ & $83 \pm 0.9$ \\
EDTA & $10 \mathrm{mM}$ & $83 \pm 1.8$ \\
EDTA & $1 \mathrm{mM}$ & $6 \pm 0.3$ \\
PMSF & $10 \mathrm{mM}$ & $3 \pm 0.3$ \\
PMSF & $1 \mathrm{mM}$ & $103 \pm 1.1$ \\
Iodoacetic acid & $10 \mathrm{mM}$ & $100.7 \pm 0.5$ \\
Iodoacetic acid & $0.1 \mathrm{mM}$ & $100.5 \pm 2.3$ \\
Pepstatin A & & \\
\hline
\end{tabular}

* Data are show as relative activity (\%) \pm SD.

concentrations of 1 and $10 \mathrm{mM}$, respectively (Table 8). Anitha and Palanivelu (2013), also observed the inhibition by PMSF in studies with protease secreted by Aspergillus parasiticus. When subjected to the concentration of $0.1 \mathrm{mM}$ PMSF, it showed a relative activity of around $2 \%$. However, the $1 \mathrm{mM}$ concentration did not show catalytic properties. Likewise, Zanphorlin et al. (2011), found a complete enzyme inhibition produced by thermophile Myceliophthora sp. under the influence of PMSF ( $5 \mathrm{mM}$ ). Cavello et al. (2013) found that the protease secreted by Purpureocillium lilacinum LPS\#876 showed a $1.8 \%$ relative activity in the presence of 1.0 mM PMSF. Enzyme inhibition by PMSF suggests the inclusion of these enzymes in the group of serine proteases.

\subsection{Determination of the molecular weight and zymography}

The evaluation of the electrophoretic profile of proteins present in the crude extract secreted by psychrophile Acremonium sp. L1$4 \mathrm{~B}$ enabled to detect the presence of distinct bands. However, the protease possibly has molecular weight of $59 \mathrm{kDa}$ visualized through of zymography containing gelatin as substrate (Fig. 4). Different molecular weights were found in protease of psychrophilic microorganisms such as Pseudoalteromonas sp. NJ276, which had $28 \mathrm{kDa}$ (Wang et al., 2008); Flavobacterium psychrophilum, $62 \mathrm{kDa}$ (Secades et al., 2003); Pedobacter cryoconitis, $27 \mathrm{kDa}$ (Margesin et al., 2008); and Pseudomonas sp., 45 kDa (Vazquez et al., 2004).

\section{Conclusion}

The $2^{3}$ factorial design, associated with central composite design under response surface methodology proved to be a set of indispensable tools for establish a dynamic and efficient protease production method, through of the fungus Acremonium sp. L1-4B and cactus pear (Opuntia ficus-indica Mill.). The serine protease obtained in the study showed stability in all tested $\mathrm{pH}$ ranges, tolerance to different $\mathrm{NaCl}$ concentrations, surfactants, bleaching agents and reducing agents, as well as to chemical denaturant, thus exhibiting characteristics that suggest a great variety of applications in biotechnology processes. 


\section{Lane 1 Lane 2}

\section{$97.0 \mathrm{kDa}$}

66.0 kDa

45.0 kDa
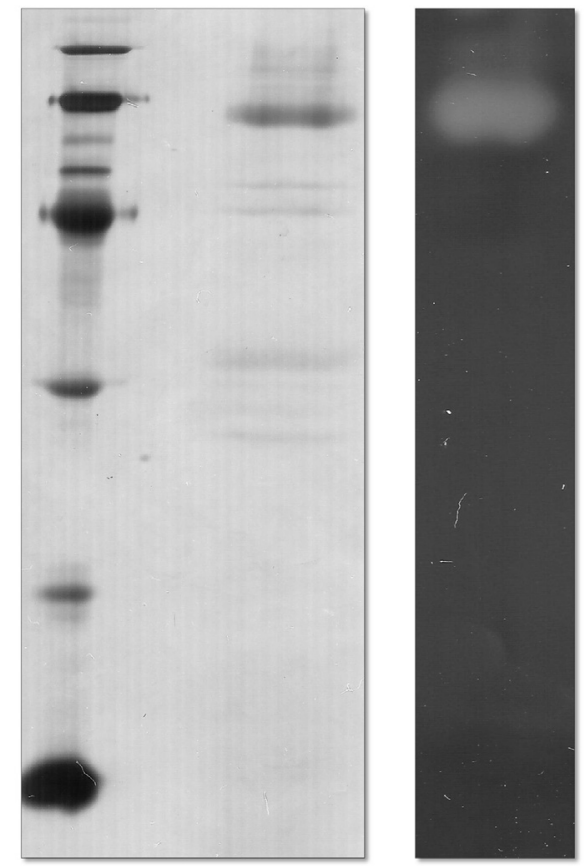

Fig. 4. SDS-PAGE and zymogram analysis of the protease from Acremonium sp. L14B. Lane 1: molecular weight of marker standard (14.4 kDa $-\alpha$-Lactalbumin, $20.1 \mathrm{kDa}$ - trypsin inhibitor, $30.0 \mathrm{kDa}$ - carbonic anhydrase, $45.0 \mathrm{kDa}$ - ovalbumin, $66.0 \mathrm{kDa}$ - bovine serum albumin, $97.0 \mathrm{kDa}$ - phosphorylase B); lane 2: crude enzyme extract; lane 3: zymography.

\section{Acknowledgments}

The authors thank State of São Paulo Research Foundation (FAPESP Grant 2013/19486-0) and Capes (PROCAD NF 717/2010). The Rural Federal University of Pernambuco. The Foundation for Research Support of the State of Pernambuco (FACEPE), for financial and structural support.

\section{References}

Abidia, F., Chobertb, J.M., Haertléb, T., Marzoukia, M.N., 2011. Purification and biochemical characterization of stable alkaline protease Prot-2 from Botrytis cinerea. Process. Biochem. 46, 2301-2310.

Anitha, T.S., Palanivelu, P., 2013. Purification and characterization of an extracellular keratinolytic protease from a new isolate of Aspergillus parasiticus. Protein Express. Purif. 88, 214-220.

Annamalai, N., Rajeswari, M.V., Balasubramanian, T., 2014. Extraction, purification and application of thermostable and halostable alkaline protease from Bacillus alveayuensis CAS 5 using marine wastes. Food Bioprod. Process. 92 (4), 335-342.

Badoei-Dalfard, A., Karami, Z., 2013. Screening and isolation of an organic solvent tolerant-protease from Bacillus sp. JER02: Activity optimization by response surface methodology. J. Mol. Catal. B Enzym. 89, 15-23.

Bezerra, J.D.P., Santos, M.G.S., Svedese, V.M., Lima, D.M.M., Fernandes, M.J.S., Paiva, L.M., Souza-Motta, C.M., 2012. Richness of endophytic fungi isolated from Opuntia ficus-indica Mill. (Cactaceae) and preliminary screening for enzyme production. World J. Microb. Biot. 28, 1989-1995.

Castro, R.J.S., Sato, H.H., 2013. Synergistic effects of agroindustrial wastes on simultaneous production of protease and $\alpha$-amylase under solid state fermentation using a simplex centroid mixture design. Ind. Crop. Prod. 49, 813-821.

Cavello, I.A., Hours, R.A., Rojas, N.L., Cavalitto, S.F., 2013. Purification and characterization of a keratinolytic serine protease from Purpureocillium lilacinum LPS \# 876. Process. Biochem. 48, 972-978.

Charney, J., Tomarelli, R.M., 1947. A colorimetric method for the determination of the proteolytic activity of duodenal juice. J. Biol. Chem. 170 (23), 501-505.

Egito, A.S., Girardet, J.M., Laguna, L.E., Poirson, C., Mollé, D., Miclo, L., Humbert, G. Gaillard, J.L., 2007. Milk-clotting activity of enzyme extracts from sunflower and albizia seeds and specific hydrolysis of bovine k-casein. Int. Dairy J. 17, 816-825.

Fleuri, L.F., Sato, H.H., 2008. Study of different parameters in the production of lytic enzymes. Food Sci. Technol. 28 (2), 299-310.

Gomes, J.E.G., Nascimento, T.C.E.S., Queiroz, A.E.S.F., Júnior, J.I.S.S., Souza-Motta, C. M., Medeiros, E.V., Moreira, K.A., 2014. Production, characterization and evaluation of in vitro digestion of phytases, xylanases and cellulases for feed industry. Afr. J. Microbiol. Res. 8 (6), 551-558.

Gomes, J., Steiner, W., 2004. Extremophiles and extremozymes. Food Technol. Biotechnol. 42 (4), 223-235.

Irwin, J.A., Alfredsson, G.A., Lanzetti, A.J., Gudmundsson, H.M., Engel, P.C., 2001. Purification and characterisation of a serine peptidase from the marine psychrophile strain PA-43. FEMS Microbiol. Lett. 201, 285-290.

Joshi, S., Satyanarayana, T., 2013. Biotechnology of cold-active proteases. Biology 2 $755-783$

Kammoun, R., Naili, B., Bejar, S., 2008. Application of a statistical design to the optimization of parameters and culture medium for amylase production by Aspergillus oryzae CBS 819.72 grown on gruel (wheat grinding by-product). Bioresour. Technol. 99, 5602-5609.

Kumar, R.S., Ananthan, G., Prabhu, A.S., 2014. Optimization of medium composition for alkaline protease production by Marinobacter sp. GA CAS9 using response surface methodology - a statistical approach. Biocatal. Agric. Biotechnol. 3, 191-197.

Kumar, A.P.K., Suresh, P.V., 2014. Biodegradation of shrimp biowaste by marine Exiguobacterium sp. CFR26M and concomitant production of extracellular protease and antioxidant materials: production and process optimization by response surface methodology. Mar. Biotechnol. 16, 202-218.

Laemmli, U.K., 1970. Cleavage of structural proteins during the assembly of the head of bacteriophage T4. Nature 227 (5259), 680-685.

Maciel, M.H.C., Herculano, P.N., Porto, T.S., Teixeira, M.E.S., Moreira, K.A., SouzaMotta, C.M., 2011. Production and partial characterization of pectinases from forage palm by Aspergillus niger URM4645. Afr. J. Biotechnol. 10 (13), 2469-2475.

Margesin, R., Dieplinger, H., Hofmann, J., Sarg, B., Lindner, H., 2008. A cold-active extracellular metalloprotease from Pedobacter cryoconitis - production and properties. Res. Microbiol. 156 (4), 499-505.

Maruthiah, T., Esakkiraj, P., Prabakaran, G., Palavesam, A., Immanuel, G., 2013. Purification and characterization of moderately halophilic alkaline serine protease from marine Bacillus subtilis AP-MSU 6. Biocatal. Agric. Biotechnol. 2, 115-119.

Meena, P., Tripathi, A.D., Srivastava, S.K., Jha, A., 2013. Utilization of agro-industria waste (wheat bran) for alkaline protease production by Pseudomonas aeruginosa in SSF using Taguchi (DOE) methodology. Biocatal. Agric. Biotechnol. 2, $210-216$.

Mnif, I., Chaabouni-Ellouze, S., Ghribi, D., 2012. Optimization of the nutritional parameters for enhanced production of $B$. subtilis SPB1 biosurfactant in submerged culture using response surface methodology. Biotechnol. Res. Int. 2012 $1-8$.

Oliveira, A.S.C., Filho, F.N.C., Rangel, A.H.N., Lopes, K.B.P., 2011. The cactus pear: alternative to the semi-arid. Rev. Verde. Agroecologia desenvolv Sustent 6 (3), 49-58.

Sáenz, C., Sepúlveda, E., Matsuhiro, B., 2004. Opuntia spp. mucilage’s a functional component with industrial perspectives. J. Arid. Environ. 57, 275-290.

Savitha, S., Sadhasivam, S., Swaminathan, K., LIN, F.H., 2011. Fungal protease: production, purification and compatibility with laundry detergents and their wash performance. J. Taiwan Inst. Chem. Eng. 42 (2), 298-304.

Secades, P., Alvarez, B., Guijarro, J.A., 2003. Purification and properties of a new psychrophilic metalloprotease (Fpp2) in the fish pathogen Flavobacterium psychrophilum. FEMS Microbiol. Lett. 226, 273-279.

Shankar, S., Rao, M., Laxman, R.S., 2011. Purification and characterization of an alkaline protease by a new strain of Beauveria sp. Process. Biochem. 46, 579-585.

Shabbiri, K., Adnan, A., Jamil, S., Ahmad, W., Noor, B., Rafique, H.M., 2012. Medium optimization of protease production by Brevibacterium linens DSM 20158, using statistical approach. Braz. J. Microbiol. 43 (3), 1051-1061.

Siddiqui, K.S., Cavicchioli, R., 2006. Cold-adapted enzymes. Annu. Rev. Biochem. 75 , $403-433$.

Vazquez, S.C., Coria, S.H., Mac Cormack, W.P., 2004. Extracellular proteases from eight psychrotolerant Antarctic strains. Microbiol. Res. 159, 157-166.

Vázquez, S.C., Hernández, E., Mac Cormack, W.P., 2008. Extracellular proteases from the Antarctic marine Pseudoalteromonas sp. P96-47 strain. Rev. Argent. Microbiol. 40, 63-71.

Wang, Q.F., Hou, Y.H., Xu, Z., Miao, J.L., Li, G.Y., 2008. Purification and properties of an extracellular cold-active protease from the psychrophilic bacterium Pseudoalteromonas sp. NJ276. Biochem. Eng. J. 38, 362-368.

Zanphorlin, L.M., Cabral, H., Arantes, E., Assis, D., Juliano, L., Juliano, M.A., Da-Silva, R., Gomes, E., Bonilla-Rodriguez, G.O., 2011. Purification and characterization of a new alkaline serine protease from the thermophilic fungus Myceliophthora sp. Process. Biochem, 46, 2137-2143. 